\title{
Influence of Socio-Psychological Factors on Consumer Willingness to Pay (WTP) for Organic Food Products
}

\author{
Lloyd J. S Baiyegunhi ${ }^{*}$, Sikhumbuzo E. Mashabane, Nonjabulo C. Sambo \\ University of KwaZulu-Natal, Pietermaritzburg, South Africa \\ Baiyegunhil@ukzn.ac.za
}

\begin{abstract}
This study evaluates consumers' willingness to pay (WTP) a premium for organic vegetables and fruits in Pietermaritzburg metropolis, KwaZulu-Natal province, South Africa, using data collected from 210 consumers approached during their food shopping. The standard economic approach to valuation was extended by including psychological factors. The results from the empirical model show that psychological factors (behavioural control, attitude and subjective norms) exerted more influence on consumers' WTP for organic products. In addition, socio-demographic factors such as gender, education, number of children in a household, high income and race, are statistically significant in explaining consumers' WTP for organic food. Policy implications for advancement and improved promotion, sales and consumption of organic food products were discussed.
\end{abstract}

Keywords: Organic food; price premium; consumers' perceptions; psychological factors; theory of planned behavior; ordered logit model

\section{Introduction}

Organic food products are food produced by an agricultural production system without the use of artificial fertilisers, pesticides, and often do not contain artificial colouring, flavouring, aromatic substances, preservatives, nor genetically modified ingredients (DAFF 2012; Stobberlaar et al., 2006), which are generally more expensive and less harmful to the environment than their conventional counterparts are. Consumer perception of organic food's quality and safety as better than the conventional foods has driven the increase in demand for organic food products all over the world (Vindigni et al., 2002). This has resulted in an upsurge in the number of farmers, distribution networks/retail outlets and consumers' willing to buy and pay a premium price for nutritive and healthy organic foods (Sharfie and Rennie 2012; Sarma and Raha 2016; Nandi et al., 2017). For many consumers, food safety, quality and it's nutrition/health benefits have become a priority (Sarma and Raha, 2016). However, organic products are relatively expensive compared to conventional food products (Roitner-Schobesberger et al., 2008). The extra percentage charged on organic food when compared to the price of non-organic food is the price premium (Shafie and Rennie, 2012).

According to Hamm et al., (2002), food safety, nature conservation and taste are the most important attributes use in substantiating organic food price premium. While some consumer alleged that the organic food market charges more for organic food, others often assumed they cannot pay for organic food others (Whitehead and Nicholson, 2001), and therefore are not willing to pay a premium price. Evidently, one of the major determinants of organic food products purchase is the price. When there is a wide price gap, there is likely to be a substantial difference in consumers' WTP price premiums for organic foods (Thompson 1998). The maximum additional price premium charge on a product a consumer is willing to pay when compared with the price of an alternative product is the "willingness to pay" (WTP). Many studies (Gil et al., 2000; Corsi and Novelli 2003; Conner and Christy 2004; Goldberg and Roosen 2005; Onozaka et al., 2006; Ghorbani and Hamraz 2009; Hagjou et al., 2013) on consumers' WTP for organic food products, have applied Contingent Valuation Model (CVM) based on stated preferences. In order to value non-market goods, the CVM is one of the economic models often used.

In contrast to a price based preference model, the CVM model is a stated preference model, in which the consumers confront an assumed buying position. The consumers are expected to respond to questions on the price they are willing to pay for organic food products or if they are prepared to pay a certain premium stated as a sum of money or as a fraction over the reference price (Carmona-Torres and Calatrava-Requena 2006). While economists have tended to match intended or stated WTP with tangible payments, they have mostly failed investigates what motivates respondents to answer to higher price premium ab initio. An 
understanding of respondents' behavioural intentions, for example, stated WTP involve the examination of psychological factors (Voon et al., 2011; Arvola et al., 2008; Ajzen et al., 1991).

The theory of planned behaviour, which is dependent or influenced by a combination three psychological factors of attitude, subjective and behavioural norms (Ajzen 1991) has been widely used in consumer behaviour study to explain buying intentions of consumers (Spash et al., 2009; Voon et al., 2011). Therefore, psychological factors can be included into contingent valuation model (CVM) to test the assumptions about motives for willingness to pay price premium (bids). For this reason, in this study, standard economic approach to valuation was extended to include the theory of planned behaviour and other socio-demographic factors based on empirical evidence from works on consumers' WTP for organic products. Health and environmental safety issues have led to changing food consumption patterns resulting in increased interest in organic food as well as creating an emerging market for organic food products throughout the world. Thus, there is a need for researchers to examine the influence of socio-demographic and psychological factors, which has not been tested or modelled within a contingent valuation model (CVM) in explaining consumers' WTP a price premium for organic food products in South Africa, which this study seeks to explore. An understanding of these elements is crucial for the design of an effective marketing stratagem for the local organic product market growth in South Africa.

\section{Literature Review}

The Theory of Planned Behaviour: The theory planned behaviour assumes a persons' intention is based on or influenced by a mix of behavioural attitudes (i.e. a persons' beliefs of the desirability of a behaviour); subjective norms (i.e. a persons' seeming relevance and importance of opinions of significant others); and behavioural control (i.e. an individual's sense of control over the behaviour) (Ajzen 1991). A person's attitude is a unique and most vital precursor for forecasting and elucidating consumers' selections across products and services as well as food products (Honkanen, et al., 2006). Attitude towards behaviour refers to a person's belief about the desirability of the behaviours i.e. either positive or negative assessment or consideration of the behaviour. It is defined as a psychological paradigm that represents a persons' willingness to behave or respond in a particular way (Jung 1971). It is a mental inclination that is borne by assessing a specific object with some amount of like or dislike (Eagly and Chaiken 1993), or a continuing evaluation of an entity alongside other alternatives, which is built on a person's emotions (affection), thoughts (cognition) and beliefs (values) towards the entity (Dossey and Keegan 2009; Hoyer and Maclnis 2004). Past research has hinged organic food consumption on behavioural attitudes such as environmental and health awareness, the trust of organic food claims and appeal of organic food qualities such as freshness, texture and taste (Aryal et al., 2009; Hughner, et al., 2007; Gil and Soler 2006; Thogersen 2006).

Since organic food is mostly perceived as more nutritive and harmless than conventionally produced food, there is a likelihood for health-conscious people to affirm the health-improving features of organic food (Michaelidou and Hassan 2008). Trust is defined as assurance in a person's anticipations, while needed behaviours are seen as definite while unwanted behaviours are not considered (Luhmann 1979). Organic food assertions trust is a strong reason for intention to consume due to organic food credibility stand. Credence food products are those that consumers are unable to appraise well because the consumption benefits are not observed immediately or directly. Consequently, consumers often rely on product tagging (labelling), advertisements and endorsements as pointers of the credibility of product claims. The degree which these provoke buyer trust will thus encourage organic food consumption intentions. In sum, a positive attitude towards organic food has the most likelihood of boosting a person's intention and WTP for organic food products. In another vein, subjective norms denote an individual's apparent relevance or social pressure or importance of opinions of significant others to perform a specific behaviour (O'Neal 2007; Ajzen 1991). Consumers' subjective norms reveal their opinions of how those they considered important to them, would see them when they take on certain behavior. In line with McClelland's (1987) theory of needs, a person is inclined to take on a behavior that is viewed necessary by referent group or loved ones, owing to their need for association and group participation.

This way, the likelihood of an individual's intention to consume organic food is boosted if they are of the opinion that the expectation of the ones they love is to do so, or if their intention is to be associated or 
identified with some organic food-consuming households (Chen 2007). Behavioural control refers to a person's awareness of the extent they are able to accomplish a particular behavior (Ajzen 1991). It refers to the sense of control over the behaviour or the ease or difficulty of performing the behaviour. The basis of such awareness is a person's beliefs about the relative easiness or exertion in accomplishing the behavior and the degree to which the performance is up to them (Ajzen 1991, cited in Tarkiainen and Sundqvist 2005). If there is relative ease of performing a behavior, and is within the means of the person, there will be a reinforced intention to perform the behavior. Previous research has classified affordability as a subclass of behavioral control that influences behavioral intention (Oh and Hsu 2001; Notani 1997; Thompson and Thompson 1996). Affordability is the capability of bearing the cost of a behavior short of any severe loss to the capability for action. For buyers, affordability is strictly related to search (convenience) and monetary costs.

\section{Methodology}

Study Area: This study was conducted in Pietermaritzburg metropolis in KwaZulu-Natal Province, South Africa, using a multistage stage sampling method to collect cross-sectional data from consumers in the metropolis. Pietermaritzburg was selected due to its strategic location as the administrative headquarters of the KwaZulu-Natal Province. Furthermore, it provides a representative sample of interest because the Pietermaritzburg metropolis is seen as a liberal metropolis socially and economically. It is densely populated and is made up of people from diverse races, educational level and income class.

Research Procedure: Ethical clearance and permission to conduct this study were obtained from the, University of KwaZulu-Natal, Humanities and Social Science Research Ethics Committee.

Respondents and Data Collection: The respondents were requested to participate freely in the survey. They were assured of the privacy, anonymity, and confidentiality of the data collected from them and signed an informed consent form. Four enumerators were trained to administer questionnaires to respondent consumers personally at each of the six malls (Hayfields, Sidewalk, Scottsville, Maritzburg, Midlands and Edendale) and a traditional local market (Debbie Market) that were purposively selected in the first stage of the study to ensure a widespread across the metropolis. The second stage involved purposive and convenient selection of consumers during their shopping for organic foods (different fruits and vegetables) with the major safe food labels/tags, and the price displayed. This method is appropriate because of the challenge in identifying the target population and is suitable where group membership is difficult to establish in order to describe a particular identifiable group. Although, the sample group might not embody the broad populations, the fact the consumers were seen buying organic food products, implies that the chosen respondents provide a remarkable study group for this study. Thirty consumers were interviewed at each mall and the traditional market, giving 210 respondent consumers used for the study.

Measuring Instrument: The opinions of consumers that participated in the study were sought using openended and close-ended questions consisting of responses that were pre-coded in a face-to-face interview, using a structured questionnaire. This is a more reliable method in CVM studies (Carson and Hanemann 2005). The survey included questions on consumers' socio-economic and demographic characteristics of respondents, attitudes towards organic vegetables and fruits; perceived societal/social beliefs of organic food consumption; concern towards environment and health, and WTP premium prices for organic vegetables and fruits. The perceptions questions were measured on a five-point Likert scale (ranging from $5=$ strongly agree, 4 = agree, 3 = neutral, 2 = disagree to $1=$ strongly disagree). Reliability analysis of scores from the consumer willingness to pay survey purchase intention, showed Cronbach alphas of 0.96 , which implies a great degree of internal dependability.

Conceptual Framework of CVM for Estimating Consumers' WTP for Organic Food Product: Within the framework of consumer-stated preference, consumers' WTP premium price for any food item is seen as a choice problem. In this framework, consumers' stated behaviour in a hypothetical setting was used to assess the value of non-market goods. It is assumed that a rational consumer $i$ will choose from a package of organic food products $\left(\varphi^{1}\right)$ and conventional products $\left(\varphi^{0}\right)$ based on his/her consumers' attitude, behavioural control and subjective norms. Thus, if the expected consumers' attitude, behavioural control and subjective 
norms toward consuming organic products $\boldsymbol{E}\left[\mathrm{U}\left(\varphi^{1}\right)_{i}\right]$ is positive and higher than those associated with consuming conventional food products $\boldsymbol{E}\left[\mathrm{U}\left(\varphi^{0}\right)_{i}\right]$, then the consumer is WTP premium price for the given organic food product. WTP premium price for an organic food product is stated as a function of a change in the consumers' attitude, behavioural control and subjective norms that arise based on the consumers' choice: WTP $=f\left[\Delta \bigcup\left(\varphi^{0}\right)_{i}\right]$, where $\Delta \bigcup(\varphi)$ is a measure of the change in attitude, subjective norms and behavioural control.

A consumer will particularly choose organic food products $\varphi^{1}$ above conventional food products $\varphi^{0}$ if the change in attitude, subjective norms and behavioural control is positive $\left[\Delta \bigcup(\varphi)=\bigcup\left(\varphi^{1}\right)-\bigcup\left(\varphi^{0}\right)>0\right]$ for all $\varphi^{1} \neq \varphi^{0}$. However, a consumers' attitude, behavioural control and subjective norms are not observable, what is observable is whether a consumer chooses to pay a premium price for organic food, or not. In order to analyse the consumers' choice behaviour, the double-bounded dichotomous choice framework was used (Hanemann et al., 1991). This approach allows two successive bids to be offered to the consumer. The second bid is conditional on the reply to the first bid. A bid is the price of the organic food offered to the consumer. Since, the price of the organic food product is not determined by the consumers, neither do they negotiate on the price of chosen products, the WTP estimates used in this study are derived from a base price that is equivalent to the average market price of organic fruits and vegetables.

Furthermore, since selection for the study was based on consumer's interest in buying organic food products, the randomly selected consumers are expected to have a price for organic food products that is equal or above the price in the retail shops. Consequently, they were asked if they are willing to buy organic food products at higher prices that were $10 \%, 20 \%, 30 \%, 40 \%$ or more than $50 \%$ over the present price. Each consumer is asked if he/she would pay only one of these premium prices. If a consumer response was " $N O^{\text {" to }}$ the first bid, then the elicitation process ends. If the answer to the first bid was ' $Y E S^{\prime}$ ", the consumer is offered a higher bid the other possible responses would be a "YES", "NO", implying an acceptance of the first bid, but rejection of the second bid, and a "YES", "YES" response, would imply acceptance of both the first and the second bids.

The Empirical Model: This study applied an ordered logit model (Greene 2008) to analyse consumers WTP a premium for the organic product. In the empirical application, three outcomes with respect to WTP for organic produce considered. The different outcomes are clearly ranked - (i) a consumer may not be WTP a premium, (ii) a consumer may accept the first bid but reject the second bid, or (iii) a willingness to pay a premium by accepting both bids.

The WTP model can be stated as follows:

$$
\Psi_{i}^{*}=X_{i}^{\prime} \beta+\varepsilon_{i}
$$

Where $\Psi_{i}^{*}$ is a latent variable that is unobservable, reflecting the WTP for organic food products by consumer $i$, stated in terms attitude, subjective norms and behavioural control, to switch from conventional organic food to organic food. $\beta$ is a vector of parameters showing the relationships amongst WTP a premium and the explanatory variables $X$ while $\varepsilon$ Is the stochastic error term. $\Psi_{i}$ Is the observable event, which indexes consumers' WTP? The relationship between the unobserved $\Psi_{i}^{*}$ and the observed outcome for consumer $i$, for $\Psi_{i}\left(\Psi_{i}=0,1,2\right)$ and is stated as follows:

$$
\begin{array}{ll}
\Psi_{i}=0 & \text { if } \Psi_{i}^{*} \leq \mu_{1} \\
\Psi_{i}=1 & \text { if } \mu_{1}<\Psi_{i}^{*} \leq \mu_{2} \\
\Psi_{i}=2 & \text { if } \mu_{2} \leq \Psi_{i}^{*}
\end{array}
$$


Equation (2) is a system of censoring and the $\mu$ 's unknown parameters, which would be estimated with $\beta$. It is assumed to be normally distributed through all observations. When the mean and variance of $\varepsilon$ is normalised to 0 and 1 respectively, the resulting probabilities are:

$$
\begin{aligned}
& \operatorname{Pr} \boldsymbol{o b}\left(\Psi_{i}=0 \mid \boldsymbol{X}\right)=\boldsymbol{f}\left(-\boldsymbol{X}^{\prime} \beta\right) \\
& \operatorname{Pr} \boldsymbol{o b}\left(\Psi_{i}=1 \mid \boldsymbol{X}\right)=\boldsymbol{f}\left(\mu_{1}-\boldsymbol{X}^{\prime} \beta\right)-\boldsymbol{f}\left(-\boldsymbol{X}^{\prime} \beta\right) \\
& \operatorname{Pr} \boldsymbol{o b}\left(\Psi_{i}=2 \mid \boldsymbol{X}\right)=\boldsymbol{f}\left(\mu_{2}-\boldsymbol{X}^{\prime} \beta\right)-\boldsymbol{f}\left(\mu_{1}-\boldsymbol{X}^{\prime} \beta\right)
\end{aligned}
$$

As all probabilities need to be positive, the condition $0<\mu_{1}<\mu_{2}$ is necessary and must satisfied and since the coefficients from the model are not equal to the marginal effects of the regresses $X$ on the probabilities, the changes in the explanatory variables estimated as the marginal effects were calculated (Maddala 1991 and Greene 2008) as specified below:

$$
\begin{aligned}
& \frac{\partial \boldsymbol{p r o b}(\Psi=0 \mid X)}{\partial X_{i}}=-\boldsymbol{f}\left(-X^{\prime} \beta\right) \beta \\
& \frac{\partial \boldsymbol{p r o b}(\Psi=1 \mid X)}{\partial X_{i}}=\left[\boldsymbol{f}\left(-X^{\prime} \beta\right)-\boldsymbol{f}\left(\mu_{1}-X^{\prime} \beta\right)\right] \beta \\
& \frac{\partial \boldsymbol{p r o b}(\Psi=2 \mid X)}{\partial X_{i}}=\left[\boldsymbol{f}\left(\mu_{1}-X^{\prime} \beta\right)-\left(\mu_{2}-X^{\prime} \beta\right)\right] \beta
\end{aligned}
$$

Explanatory Variables Included in the Empirical Model: The theory of planned behavior was measured by psychological factors such as attitude (taste, environmental and health consciousness, trust of organic food claims by retailers, organic food product knowledge, presence of chemical residues in conventional vegetables and fruits); subjective norms (spouse and children approval of organic food) and behavioral control (availability and affordability) (See Padel and Foster 2005; Michaelidou and Hassan 2008; Nandi et al., 2017). In addition, empirical evidence from past studies has shown that consumers' WTP is also influenced by

\begin{tabular}{|c|c|c|}
\hline Variables & Description & $\begin{array}{l}\text { Hypothesised } \\
\text { signs }\end{array}$ \\
\hline \multicolumn{3}{|c|}{ Socio-demographic variables: } \\
\hline Gender of household head & $\mathrm{D}=1$ if female, 0 otherwise & - \\
\hline Age & Respondent age in years & $+/-$ \\
\hline Education & Number of years of schooling & + \\
\hline Marital status & $\mathrm{D}=1$ if respondent is married; 0 otherwise & + \\
\hline Household size & $\begin{array}{l}\text { Number of people in a household (per adult } \\
\text { equivalent) }\end{array}$ & $+/-$ \\
\hline Children & Number of children younger than 18yrs & + \\
\hline Low Inc & $\begin{array}{l}\mathrm{D}=1 \text { if monthly household income is less than } \\
\mathrm{R} 5,000 ; 0 \text { otherwise }\end{array}$ & - \\
\hline Mid Inc ${ }^{a}$ & $\begin{array}{l}\mathrm{D}=1 \text { if monthly household income is less than } \\
\mathrm{R} 6,000-\mathrm{R} 10,000 ; 0 \text { otherwise }\end{array}$ & + \\
\hline High Inc & $\begin{array}{l}\mathrm{D}=1 \text { if monthly household income is greater than } \\
\mathrm{R} 10,000 ; 0 \text { otherwise }\end{array}$ & + \\
\hline Race & $\mathrm{D}=1$ if African; 0 otherwise & $+/-$ \\
\hline
\end{tabular}
socio-demographic variables such as gender, age, marital status, education, number of children below age 18, household income and the race of the consumer. (See Chelang et al., 2013; Liu et al., 2009; Haghiri et al., 2009; Darby et al., 2008; Onyango et al., 2007; Krystallis and Chryssohoids 2005). The explanatory variables used in the empirical model for this study is presented in Table 1.

\section{Table 1: Explanatory Variables Used in the Empirical Model}




\section{Attitudinal variables: \\ Taste \\ Health/nutrition benefits\# \\ Knowledge ${ }^{\#}$ \\ Trust of retailers\# \\ Chemical residues\# \\ Environmental benefit ${ }^{\#}$ \\ Subjective norms variable: \\ Loved ones expectations ${ }^{\#}$ \\ Behavioural control variables: \\ Product availability ${ }^{\#}$ \\ Affordability (Price)\# \\ Consumer perception on taste attribute of organic food \\ Consumer perception on health/nutritional attribute of organic food \\ Organic food products knowledge + \\ Consumer trust of retailers of organic food + products \\ Consumer perception about chemical residues on convectional vegetables and fruits \\ Consumer perception on environment benefits of + organic food \\ Consumer perception on spouse/children's + expectation/approval of organic food purchase \\ Consumer perception on availability of organic + food \\ Based on a priori expectations Consumer perception of the price of organic food \\ Note: a indicates the reference category, dropped from the model to avoid perfect collinearity. "indicates measurement on a $1-5$ Likert Scale.}

\section{Results and Discussion}

Descriptive Statistics of the Consumers' WTP for Organic Food: The majority of the consumers (about 67 percent) reported that they are WTP premium price for organic food products, while about 44 percent of them indicated WTP 10 percent premium price and are not WTP the 20 per cent premium price or any amount above the first bid). Only about 23 percent of the consumers indicated WTP between 10 percent premium (i.e. the first bid) and 20 percent premium (i.e. the second bid) but not any amount above 20 percent premium. The share of the consumer WTP the bid premium generally decreased with an increase in price. The distribution of consumers WTP premium price for an organic food product is presented in Table 2.

Table 2: Distribution of Consumers WTP Price Premium for Organic Food Product

\begin{tabular}{llcc}
\hline Categories & Description & $\begin{array}{c}\text { No of } \\
\text { respondents }\end{array}$ & Percentage \\
\hline No & $\begin{array}{l}\text { Not willing to pay a price premium for organic } \\
\text { products }\end{array}$ & 69 & 33 \\
Yes - No & $\begin{array}{l}\text { Willing to pay 10 per cent price premium (i.e. } \\
\text { the 1st bid) but unwilling to pay for the 2nd }\end{array}$ & 93 & 44 \\
bid. & $\begin{array}{l}\text { Willing to pay 10 per cent - 20 per cent } \\
\text { Yes - Yes } \\
\text { price premium (i.e. the 1st and 2nd bid) but not a }\end{array}$ & 48 \\
\hline Total & & 210 & 100 \\
\hline
\end{tabular}

Source: Survey data analysis.

Determinants of Consumers' WTP for Organic Food Products: The parameter estimates of the ordered logit model and its marginal effects, calculated at the sample means are presented in Table 3 . The ordered logit model results are explained using the marginal value (marginal effects), which is a probability measure of how a unit change in the explanatory variables affects the outcome variable categories. 
Table 3: Result of the Ordered Logit Regression Model for the Determinants of WTP for Organic Food Products

\begin{tabular}{|c|c|c|c|c|c|}
\hline \multirow[b]{2}{*}{ Variables } & \multirow[b]{2}{*}{$(\beta)$} & \multicolumn{3}{|c|}{ Marginal effects } & \multirow[b]{2}{*}{ Yes-Yes } \\
\hline & & SE & No & Yes-No & \\
\hline \multicolumn{6}{|c|}{ Socio-demographic variables: } \\
\hline Gender & $0.569^{* * *}$ & 0.181 & -0.049 & -0.039 & 0.089 \\
\hline Age & 0.013 & 0.032 & 0.002 & -0.001 & -0.002 \\
\hline Education & $0.310^{* * *}$ & 0.190 & -0.040 & -0.036 & 0.076 \\
\hline Marital status & 0.0002 & 0.208 & -0.000 & -0.000 & 0.000 \\
\hline Household size & 0.793 & 0.356 & 0.003 & 0.004 & -0.014 \\
\hline Children & $0.046^{* *}$ & 0.023 & -0.010 & 0.046 & 0.028 \\
\hline Low Income & 0.039 & 0.052 & 0.015 & 0.012 & 0.032 \\
\hline High Income & $0.945^{* *}$ & 0.372 & -0.050 & 0.023 & 0.046 \\
\hline African & $-0.457^{* * *}$ & 0.250 & 0.066 & -0.048 & -0.114 \\
\hline \multicolumn{6}{|l|}{ Attitude variables: } \\
\hline Taste & 0.006 & 0.071 & -0.080 & 0.037 & 0.068 \\
\hline Health/nutrition benefits & $0.064^{* *}$ & 0.025 & -0.261 & 0.182 & 0.364 \\
\hline Knowledge & $0.044^{* *}$ & 0.022 & -0.181 & 0.325 & 0.261 \\
\hline Trust of retailers & $1.683^{* *}$ & 0.751 & -0.261 & 0.313 & 0.250 \\
\hline Chemical residues & $2.320^{* * *}$ & 0.620 & -0.281 & 0.321 & 0.363 \\
\hline Environmental benefit & $1.533^{* *}$ & 0.561 & -0.162 & 0.143 & 0.284 \\
\hline \multicolumn{6}{|c|}{ Subjective norms variable: } \\
\hline Loved ones expectations & $1.453^{* * *}$ & 0.328 & -0.213 & 0.461 & 0.542 \\
\hline \multicolumn{6}{|c|}{ Behavioural control variables: } \\
\hline Product availability & $1.290^{* *}$ & 0.683 & -0.162 & 0.321 & 0.473 \\
\hline Affordability (Price) & $0.451^{* *}$ & 0.163 & 0.174 & 0.290 & 0.305 \\
\hline Constant & 5.219 & 0.111 & & & \\
\hline $\begin{array}{l}\text { Number of observation: } \\
\text { accuracy (correctly predi }\end{array}$ & $\begin{array}{l}\text { likelihood } \\
\text { per cent }\end{array}$ & 614.1; & stics & udo $\mathrm{R}^{2}$ & 64: Overal \\
\hline
\end{tabular}

The results presented in Table 3 shows that consumers' WTP for organic food products is influenced by both demographic and socio-psychological factors, with the latter exerting more influence on WTP as revealed by their marginal effects (column 3-5 in Table 3). Consumers' demographics (gender, education, number of children in a household, household income and race) have a statistically significant influence on the WTP for an organic food product. The probability of a consumers' WTP price premium for organic food product increases with female consumers the probability of a female consumer choosing a No premium option and a Yes-No option decreases by 4.9 percent and 3.9 percent respectively, while the probability of willingness to pay 20 percent premium increases by 8.9 percent. This implies that female consumers are more WTP premiums for organic products compared to their male counterparts. This is probably because women are more "family-oriented" and are concern about food nutrition, its safety and health benefits. This finding is consistent with those of Nandi et al., (2017); Omar et al., (2016); Gracia and de Magistris (2008); Liu et al., (2009); Onyango et al., (2007); Stobbelaar et al., (2006) and Krystallis and Chryssohoidis (2005), among others. The probability of a consumer choosing a No premium option and a Yes-No option decreases by 4.0 percent and 3.6 percent respectively with a year increase in education, while the probability of willingness to pay 20 per cent premium increases by 7.6 percent. The implication is that consumers are WTP premiums for organic food with a year increase in their educational attainment. These results concur with those of Gracia and de Magistris (2008); Krystallis and Chryssohoidis (2006), but the contrast with those of Boccaletti and Nardella (2000).

The educational acquisition has been shown to significantly influence consumers' attitude towards organic food products. Consumers who had acquired higher education are most likely to display positive attitudes towards organic food (Emadi and Rosta 2016; Omar et al., 2016; Liu et al., 2009; Gracia \& de Magistris 2007; Darby et al., 2008). In addition, the number of children in a household shows that the probability of a 
consumer choosing a No premium option decreases by 1.0 percent when the number of children in a household increase by one, while the probability of choosing a Yes-No and a Yes-Yes option increases by 4.6 percent and 2.8 percent respectively. This implies that a household with children age less than 18 years are WTP premiums for organic food produce. This finding is consistent with the findings of Chelang'a et al., (2013). Empirical study has shown that household with children exerts a positive influence on consumers' organic food attitude and buying behaviour (Essoussi and Zahaf 2008). The probability of high-income households choosing the No premium option decreases by 5 percent with an increase in income, while the probability of choosing the Yes-No option and the Yes-Yes option increases by 2.3 percent and 4.6 percent respectively. This implies that high-income households are WTP premium for organic food produce and more likely to form positive attitudes towards organic food (Nandi et al., 2016; Emadi et al., 2016; Adekunle et al., 2016; Gracia and de Magistris 2007; Haghiri et al., 2009; Aryal et al., 2009). The probability of an African consumer choosing the No premium option increases by 6.6 percent, while the probability of choosing the Yes- No and Yes-Yes option decreases by 4.8 percent and 11.4 percent respectively. The implication is that consumers of African descent are not WTP premium price for organic food.

A possible explanation could be that in South Africa, the majority of the African population are still poor and do not possesses economic and production assets compared to other racial groups. Furthermore, the results presented in Table 3 also shows that psychological factors such as consumers' attitude, subjective norms and behavioural control are statistically significant in explaining consumers' WTP for organic food. Specifically, consumers' attitude (knowledge of organic food product, the trust of retailers, perception on chemical residues, health/nutritional benefit, environmental benefits) are statistically significant factors influencing WTP for an organic food product. Consumers' knowledge/awareness of organic food products shows that the likelihood of choosing the No premium option decreases by 18 percent, with an increase in consumers' knowledge/awareness of organic food. The probability of choosing the Yes-No and Yes-Yes options increases by 32 percent and 26 percent respectively, implying that consumers are WTP premium price for an organic product with an increasing knowledge or awareness. The result is consistent with those of Adekunle et al., (2016); Haghiri et al., (2009); Gracia and de Magistris (2008); Gil and Soler (2006) and Govindasamy et al., (2005). Consumers' trust of organic food retailers shows that the likelihood of selecting the No premium option decreases by 26 percent, with an increase in trust perception of organic food retailers. The probability of choosing the Yes-No and Yes-Yes options increases by 31 percent and 25 percent respectively, implying that consumers are WTP premium price for an organic product with increasing trust of retail outlets/shops. Also, consumers' perception on nutrition/health benefits of organic food show that the likelihood of a consumer opting for the No premium decreases by 26 percent, with an increase in their perceptions on nutrition/health benefits.

The likelihood of choosing the Yes-No and Yes-Yes options increases respectively by 18 per cent and 36 per cent, implying that consumers are willing to pay a price premium for an organic product if they perceived that the nutrition/health benefits are great. According to Michaelidou and Hassan (2008), consumers are expected to develop positive attitudes towards the health-improving qualities of organic food products since they are mostly seen as more nutritious and safer than conventionally produced food. Furthermore, Nandi et al., (2017); Sarma and Raha (2016); Batte et al., (2007) and Padel and Foster (2005) have shown that health concern was a key factor for WTP for a product with a high percentage of organic content. Consumers' perception of conventional vegetables and fruits containing chemical residues has a statistically significant influence on WTP for organic food products. Consumers' perception of chemical residues on conventional vegetables/fruits shows that the likelihood of choosing the No premium option decreases by 28 percent, with an increase in chemical residue perception of conventional vegetables/fruits. The probability of choosing the Yes-No and Yes-Yes options increases by 32 percent and 36 percent respectively. The implication is that consumers are WTP premium price with increasing perception of the presence of chemical residues in conventional vegetables and fruits, because of the associated health risks with conventional vegetables and fruits. Consumers' perception of the environmental benefit of organic food show that the likelihood of a consumer opting for the No premium decreases by 16 percent, with an increase in their perceptions on environmental benefits.

The probability of choosing the Yes-No and Yes-Yes options increases respectively by 14 percent and 28 percent. The implication is that consumers are WTP premium price for organic food if they are perceived as 
beneficial to the environment. The empirical evidence of this finding is consistent with Honkanen et al., (2006) and Nandi et al., (2017). Studies have shown that consumers appear to support agricultural food products that are environmentally friendly and discourage any action that is detrimental to the environment and increases pollution (Lucas et al., 2008; Magnusson et al., 2003). Consumers' subjective norm (perception of loved ones approval of organic food) show that the likelihood of a consumer opting for the No premium decreases by 21 percent with an increasing approval of loved ones organic food purchase. The likelihood of choosing the Yes-No and Yes-Yes options increases by about 46 percent and 54 percent respectively, implying that consumers are WTP premium price if they perceived that their loved ones approved of their organic food products purchases. The result is consistent with Voon et al., (2011), consumers' intention to consume organic food product is strengthened if they consider that it is the expectation of their loved ones for them to do so. Consumers' behavioural control (availability and affordability) has a statistically significant influence on WTP for organic food products. The marginal value in respect of perception on product availability shows that the likelihood of a consumer opting for the No premium decreases by 16 percent with an increasing organic product price.

The likelihood of choosing the Yes-No and Yes-Yes options increases by about 32 percent and 47 percent respectively, implying that consumers are WTP premium price if they perceived organic products are readily available in the market. Consumers who are willing to buy organic food products are more likely to buy in larger quantities, if they were readily available (Gracia and de Magistris 2007; Nandi et al., 2017). Consumers' perception of price shows that the likelihood of a consumer opting for the No premium increases by 17 percent with an increasing organic product price. The likelihood of choosing the Yes-No and Yes-Yes options increases by about 29 percent and 35 percent respectively, implying that consumers were WTP premium price even when they perceived organic food product prices are too high. The result is contrary to those of Adekunle et al., (2016), Gracia and de Magistris (2008), they asserted even though there is an increasing demand for higher quality and healthy food products by consumers, they still respond changes in price. A plausible explanation for this is consumers could perceive organic food that cheap as of low quality and have fewer benefits. As a result, the organic product may lose its unique and distinctive elements and appeal among consumers. Consumers who have been convinced of the benefits of organic food and have made it consumption a lifestyle are less likely to be deterred by high prices. However, affordability could be an issue for those who do not consume organic food frequently or are yet to be influenced by its many benefits (Hughner et al., 2007; Voon et al., 2011).

\section{Conclusion and Policy Implications}

Consumers' perception of the organic food product is crucial, as it will determine the buying behaviour. The study findings show that the availability of organic food in the market will increase price and purchases. Consumers seem to be willing to accept higher prices for the organic product as they see it as a payment for the desired benefits and needed attributes of organic food. Therefore, marketers/producers should focus on how to develop strategies for increasing sales of organic food products and 00help local farmers to improve their farm production methods. In addition, in order to offer effectively their organic product lines, producers and retailers have a duty to cautiously review the price premiums charged and create awareness for organic food consumption (especially among the African population). Price is a limitation for organic food consumption. The prevailing gaps between organic and conventional food prices need to be reduced in order to encourage and promote the consumption of organic food. The provision of relevant information and developing educational promotional campaigns on organic food products are imperative for the growth of the local organic food market. Marketing strategies could include promotional trials of the products in retail outlets and by providing information on how organic foods are produced, as well as on the health, nutritional and environmental benefits.

This will attract new consumers and increase their understanding of the term "organic". Furthermore, individuals whom consumers hold in high regard should continue to influence them through their active advice or opinions as well as passively through their own behaviours. In addition, since the socio-economic and psychological factors determining consumers' WTP premium price for organic food products are varied, marketing approaches for promoting organic food consumption will be successful if salespersons target educated female consumers, with a high income and young children. However, a limitation of the study is the 
restriction of the survey only to Pietermaritzburg metropolis. Therefore, more studies covering larger geographical areas could build on the findings of this study and expand the strength of the results. Secondly, this study is based on willingness to pay (intention/stated preference); future studies may focus on actual purchase (revealed preference).

Conflict of Interest: We hereby declared that there is no conflict of interest in this study.

\section{References}

Adekunle, C. P., Akerele, D., Adekunle, A. K. \& Amodemaja, T. S. (2016). Consumers' willingness to pay for organic leafy vegetables in Abeokuta South West Nigeria. Double bounded dichotomous choice approach. Nigerian Journal of Agriculture, Food and Environment, 12(1), 17-23.

Ajzen, I. (1991). The theory of planned behavior. Organizational Behavior and Human Decision Processes, 5(2), 179-211.

Arvola, A., Vassalo, M., Dean, M., Lampila P., Saba, A., Lahteenmaki, L. \& Shepherd, R. (2008). Predicting intentions to purchase organic food: The role of a00ffective and moral attitudes in the Theory of Planned Behavior, Appetite, 50, 443-454.

Aryal, K. P., Chaudhary, P., Pandit, S. \& Sharma, G. (2009). Consumers' willingness to pay for organic products: a case from the Kathmandu valley. Journal of Agriculture and Environment, 10, 12-22.

Batte, M. T., Hooker, N., Haab, T. C. \& Beaverson, J. (2007). Putting their money where their mouths are: consumer willingness to pay for multi-ingredient, processed organic food products. Food Policy, 32(2), 145-159.

Boccaletti, S. \& Nardella, M. (2000). Consumer willingness to pay for pesticide-free fresh fruit and vegetables in Italy. International Food and Agribusiness Management Review, 3(3), 297-310.

Carmona-Torres, M. \& Calatrava-Requena, J. (2006). Bid design and its influence on the stated willingness to pay in a contingent valuation study. Contributed paper prepared for presentation at the International Association of Agricultural Economists Conference, Gold Coast, Australia.

Carson, R. T. \& Hanemann, W. M. (2005). Contingent valuation in Maler, K. G. and J. R. Vincent (Eds), Handbook of Environmental Economics, 2, 517-1103.

Chelang'a, P. K., Obare, G. A. \& Kimenju, S. C. (2013). Analysis of urban consumers' willingness to pay a premium for African leafy vegetables (ALVs) in Kenya: a case study of Eldoret Town. Food Security, 5, 591-595.

Chen, M. F. (2007). Consumer attitudes and purchase intentions in relation to organic foods in Taiwan: Moderating effects of food-related personality traits. Food Quality and Preference, 18, 1008-1021.

Conner, D. S. \& Christy, R. D. (2004). The organic label: how to reconcile its meaning with consumer preferences. Journal of Food Distribution Research, 35(1), 40-43.

Corsi, A. \& Novelli, S. (2003). Measuring quantity constrained and maximum prices consumers are willing to pay for quality improvements: The case of organic beef meat. Proceedings of the 25th IAAE Conference, Durban, South Africa.

Darby, K., Batte, M. T., Ernst, S. \& Roe, B. (2008). Decomposing local: A conjoint analysis of locally produced foods. American Journal of Agricultural Economics, 90(2), 76-486.

DAFF. (2012). National policy on organic production. Confidential discussion paper 7th draft. Department of Agriculture, Forests and Fisheries, Pretoria. Republic of South Africa.

Dossey, B. M. \& Keegan, L. (2009). Holistic Nursing: A Handbook for Practice, Sad bury, MA: Jones and Bartlett Publishers.

Eagly, A. H. \& Chaiken, S. (1993). The psychology of attitudes. Harcourt Brace Jovanovich, ISBN 0155000977 Fort Worth, Texas, USA.

Emadi, A. \& Rosta, A. (2016). Valuation of organic dairy products, proteins and factors affecting willingness to pay study fittings in the city of Shiraz. International Journal of Applied and Basic Sciences, 10(1), 5158.

Essoussi, L. H. \& Zahaf, M. (2008). Decision-making process of community organic food consumers: an exploratory study. Journal of Consumer Marketing, 25(2), 95-104.

Ghorbani, M. \& Hamraz, S. (2009). A survey on factors affecting on consumer's potential willingness to pay for organic products in Iran (a case study). Trends in Agricultural Economics 2, 10-16. 
Gil, J. M., Gracia, A. \& Sanchez, M. (2000). Market segmentation and willingness to pay for organic products in Spain. International Food and Agribusiness Management Review, 3(2), 207-226.

Gil, J. M. \& Soler, F. (2006). Knowledge and willingness to pay for organic food in Spain: Evidence from experimental auctions. Food Economics, 3, 109-124.

Gracia, A. \& de Magistris, T. (2007). Organic food product purchase behavior: a pilot study for urban consumers in the South of Italy. Spanish Journal of Agricultural Research, 5(4), 439-451.

Gracia, A. \& de Magistris, T. (2008). The demand for organic foods in the South of Italy: A discrete choice model. Food Policy, 33, 386-396.

Goldberg, I. \& Roosen, J. (2005). Measuring consumer willingness to pay for a health risk reduction of salmonellosis and campylo bacteriosis. EAAE Congress, Copenhagen, Denmark, August 24-27.

Govindasamy, R., DeCongelio, M. \& Bhuyan, S. (2005). An evaluation of consumer willingness to pay for organic produce in the northeastern US. Journal of Food Products Marketing, 11(4), 3-20.

Greene, W. (2008). Econometric Analysis. 6th Edition. Prentice Hall, Upper Saddle River, New Jersey.

Haghiri, M., Hobbs, J. E. \& McNamara, M. L. (2009). Assessing consumer preferences for organically grown fresh Fruit and Vegetables in Eastern New Brunswick. International Food and Agribusiness Management Review, 12(4), 81-100.

Haghjou, M., Hayati, B., Pishbahar, E., Mohammadrezaei, R. \& Dashti, G. (2013). Factors affecting consumers' potential willingness to pay for organic food products in Iran: a case study of Tabriz. Journal of Agricultural Science and Technology, 15, 191-202.

Hamm, U., Gronefeld, F. \& Haplin, D. (2002). Analysis of the European market for organic food: organic marketing initiatives and rural development, School of Management and Business. Ceredigion, Wales.

Hanemann, M. W., Loomisand, J. B. \& Kanninen, B. J. (1991). Statistical efficiency of double-bounded dichotomous choice contingent valuation. American Journal of Agricultural Economics, 73(4), 12551263.

Honkanen, P., Verplanken, B. \& Olsen, S. O. (2006). Ethical values and motives driving organic food choice. Journal of Consumer Behavior, 5(5), 420-430.

Hoyer, W. D. \& Maclnis, D. J. (2004). Consumer Behavior. Boston: Houghton Mifflin.

Hughner, R. S. P., McDonagh, P., Prothero, A. Shultz, C. J. \& Stanton, J. (2007). Who are organic food consumers? A compilation and review of why people purchase organic food, Journal of Consumer Behavior, 6, 1-17.

Jung, C. G. (1971). Psychological Types, Collected Works, Volume 6. Princeton, NJ: Princeton University Press.

Krystallis, A. \& Chryssohoidis, G. (2005). Consumers' willingness to pay for organic food: factors that affect it and variation per organic product type. British Food Journal, 107(4/5), 320-343.

Liu Y., Zeng, Y. \& Yu, X. (2009). Consumer willingness to pay for food safety in Beijing: A case study of food additives. Contributed paper prepared for presentation at the International Association of Agricultural Economists Conference, Beijing, China, 16-22.

Lucas, M. R. V., Röhrich, K., Marreiros, C., Fragoso, R., Kabbert, R., Clara, A. M. \& Böhm, S. (2008). Quality, safety and consumer behavior towards organic food in Germany and Portugal. University of Evora, CEFAGEUE (Portugal).

Luhmann, N. (1979). Trust and Power. Chichester: Wiley.

Maddala, G. S. (1991). Limited-dependent and Qualitative Variables in Econometrics. Cambridge University Press. Cambridge, UK, 46-49.

Makatouni, A. (2002). What motivates consumers to buy organic food in UK? Results from a qualitative study. British Food Journal, 104(3/4/5), 345-352.

Magnusson, M. K., Arvola, A., Hursti, U. K. K., Åberg, L. \& Sjödén, P. O. (2003). Choice of organic foods is related to perceived consequences for human health and to environmentally friendly behavior. Appetite, 40, $109-117$.

McClelland, D. C. (1987). Human Motivation. New York: Cambridge University Press.

Michaelidou, N. \& Hassan, L. M. (2008). The role of health consciousness, food safety concern and ethical identity on attitudes and intentions towards organic food. International Journal of Consumer Studies, 32(1), 163-170.

Nandi, R. Bokelmann, W. Gowdru, N. V. \& Dias, G. (2017). Factors influencing consumers' willingness to pay for organic fruits and vegetables: empirical evidence from a consumer survey in India. Journal of Food Products Marketing, 23(4), 430-451. 
Notani, A. S. (1997). Perceptions of affordability: their role in predicting purchase intent and purchase. Journal of Economic Psychology, 18, 525-546.

O'Neal, P. W. (ed.) (2007). Motivation of Health Behavior. New York: Nova Science Publishers Inc.

Onozaka, Y., Bunch, D. \& Larson, D. (2006). What exactly are they paying for? Explaining the price premium for organic fresh produce. Update: Agricultural and Resource Economics, 9, 1-4.

Oh, H. \& Hsu, C. H. C. (2001). Volitional degrees of gambling behaviors. Annals of Tourism Research, 28(3), 618-637.

Onyango, B. M., Hallman, W. K. \& Bellows, A. C. (2007). Purchasing organic food in US food systems: A study of attitudes and practice. British Food Journal, 109(5), 399-411.

Omar, N. A, Nazri, M. A., Osman, L. H. \& Ahmad M. S. (2016). The effects of demographic factors on consumers' intention to purchase organic products in the Klang Valley: an empirical study. Malaysian Journal of Society and Space, 12(2), 68-82.

Padel, S. \& Foster, C. (2005). Exploring the gap between attitudes and behavior. British Food Journal, 107(8), 606-625.

Roitner-Schobesberger, B., Darnhofer, I., Somsook, S. \& Vogl, C. R. (2008). Consumer perceptions of organic food in Bangkok, Thailand. Food Policy, 33, 112-121.

Sarma, P. K. \& Raha, S. K. (2016). Consumers' willingness to pay for organic beef: evidence from Dhaka city. Journal of Bangladesh Agricultural University, 14(1), 83-91.

Shafie, F. A. \& Rennie, D. (2012). Consumer perceptions 00towards organic food. Procedia - Social and Behavioral Sciences, 49, 360-367.

Spash, C. L., Urama, K., Burton, R., Kenyon, W., Shannon, P. \& Hill, G. (2009). Motives behind willingness to pay for improving biodiversity in a water ecosystem: economics, ethics and social psychology. Ecological Economics, 68(4), 955-964.

Stobbelaar, D. J., Casimir, G., Borghuis, J., Marks, I., Meijer, L. \& Zebeda, S. (2006). Adolescents' attitudes towards organic food: a survey of 15 to 16-year-old schoolchildren. International Journal of Consumer Studies, 31(4), 349-356.

Tarkiainen, A. \& Sundqvist, S. (2005). Subjective norms, attitudes and intentions of Finnish consumers in buying organic food. British Food Journal, 107(11), 808-822.

Thogersen, J. (2006). Predicting Consumer Choices of Organic Food: Results from the CONDOR Project, in Proceedings of European Joint Organic Congress, eds. Andreasen C.B., L. Elsgaard, S. Sondergaard, L. Sorensen and G. Hansen. 30-31, Odense, Denmark.

Thompson, N. J. \& Thompson, K. E. (1996). Reasoned action theory: an application to alcohol free beer. Journal of Marketing Practice, 2, 35-48.

Thompson, G. D. (1998). Consumer's demand for organic foods: what we know and what we need to know. American Journal of Agricultural Economics, 80(5), 1113-1118.

Vindigni, G., Janssen, M. A. \& Jager, W. (2002). Organic food consumption: a multi-theoretical framework of consumer decision making. British Food Journal, 104(8), 624-642.

Voon, J. P., Ngui, K. S. \& Agrawal, A. (2011). Determinants of willingness to purchase organic food: and explanatory studying using structural equation modeling. International Food and Agribusiness Management Review, 14(2), 103-120.

Whitehead, P. \& Nicholson, S. (2001). Organic food: niche or mainstream, IGD, Letch more Heath Wart ford. 